\section{artelogie}

\section{Artelogie}

Recherche sur les arts, le patrimoine et la littérature de l'Amérique latine

10 | 2017

Après le paysage : l'art, l'inscription et la représentation de la nature en Amérique latine aujourd'hui

\title{
Panorâmica geral
}

Jacques Leenhardt, Maria José de Azevedo Marcondes e Catalina Valdés

\section{CpenEdition}

Journals

Edição electrónica

URL: http://journals.openedition.org/artelogie/914

DOI: 10.4000/artelogie.914

ISSN: 2115-6395

Editora

Association ESCAL

Refêrencia eletrónica

Jacques Leenhardt, Maria José de Azevedo Marcondes e Catalina Valdés, "Panorâmica geral ", Artelogie [Online], 10 | 2017, posto online no dia 05 abril 2017, consultado o 23 setembro 2020. URL : http://journals.openedition.org/artelogie/914; DOI : https://doi.org/10.4000/artelogie.914

Este documento foi criado de forma automática no dia 23 setembro 2020.

Association ESCAL 


\title{
Panorâmica geral
}

\author{
Jacques Leenhardt, Maria José de Azevedo Marcondes e Catalina Valdés
}

1 Artelogie publica seu décimo número com uma série de novidades editoriais, as quais temos a satisfação de compartilhar com nossos leitores. A partir deste número, a revista integrará a plataforma de periódicos indexados na área de ciências humanas e sociais da França - Revues.org, que integra o portal OpenEdition. Além desta possibilidade, cabe assinalar que com o décimo número de Artelogie inicia-se uma colaboração com a revista Critique d'Art - publicação dos Archives de la critique d'art de Rennes, França. Através dessa colaboração, as resenhas dos livros que serão incluídos neste e nos próximos números, serão traduzidos para o idioma francês e publicados, também, na citada revista. Ressaltamos que a integração à Revues.org, assim como a colaboração com a Revue Critique d'Art, representam um reconhecimento do trabalho acadêmico e editorial desenvolvido pela Revue Artelogie nos últimos anos; inscrevendo a revista em uma rede de publicações digitais, a qual ampliará sua difusão e propiciará às pesquisas em história da arte e da cultura latino-americana uma maior visibilidade no âmbito acadêmico internacional e, em específico na França.

2 Esse novo número se propõe como uma plataforma poética e crítica de uma cartografia de artistas, de imagens, de ideias - que aborde a representação e inscrições da natureza na América Latina na arte. Com este propósito convocou pesquisadores, artistas e gestores das diversas disciplinas vinculados à produção da paisagem a apresentarem suas colaborações.

3 As premissas desta edição da Revue Artelogie partem da ideia, segundo a qual, as representações artísticas da natureza na América Latina revelam uma construção cultural matizada pelos processos de colonização europeia do continente desde o século $\mathrm{XV}$ e por sua posterior formalização como estados modernos, desde o começo do século XIX. As imagens de lugares naturais e culturais produzidas neste período, que se valeram tanto da pintura de paisagem como de outras formas de representação, são reflexo de experiências direta ou outorgadas de artistas, principalmente estrangeiros, que contribuíram para criar um imaginário determinado pelo exótico, o exuberante, o sublime ou o pitoresco. A partir da apropriação de modelos estéticos de tradição europeia, as imagens da natureza americana entraram em tensão, diálogo ou 
combinação com a cultura material e imaterial local. Assim configuram padrões epistemológicos (estéticos e científicos) de apropriação da realidade específica da região.

4 Desde uma posição crítica pós-colonial tem surgido nos últimos anos obras de arte e estudos de reinscrição histórica que nos revelam o poder colonizador que podem exercer as representações visuais da natureza americana produzidas por (e em princípio, também, para) a mirada europeia. A citada revisão crítica, ao mesmo tempo, tem detectado os deslocamentos e interferências cognitivas e estéticas que o encontro entre Europa e América desencadeou em ambos os sentidos, transformando, de um modo determinante, a relação dos sujeitos com o entorno natural.

5 Para este marco destacado dos estudos sobre a história da arte latino-americana, a pintura da paisagem do século XIX, constitui-se em um dos artefatos que melhor permite revisar as funções da imagem nos processos de formação de identidades sociais. Esta perspectiva não perde de vista, as questões contingentes que a paisagem coloca, como gênero pictórico e como manifestação de um processo mais amplo que induziu a imaginários e territórios aos cânones da modernidade secular. Em outros termos a pintura da paisagem homologou os modos de abordar a representação de lugares, ocupando frequentemente um notável papel nos processos de formação de identidades nacionais, mas também levantando questões contingentes, visíveis a través de um olhar contemporâneo e crítico.

6 Até o final do século XIX e começo do XX, escritores e os artistas locais se aproximaram da paisagem experimentando novas formas e estilos; recorrendo a abstração, a materialidades e técnicas não convencionais. Por meio de imagens com um recorte político, reafirmaram uma identidade local desde uma visão renovada das noções de nacionalismo, indianismo ou latino-americanismo. Nelas, a natureza parece ocupar a função de matéria-prima, garantia da utopia modernizadora.

7 Hoje, devido a contingência de uma natureza ameaçada - e ameaçante - cabe indagar sobre a relocalização da condição humana no âmbito do natural e na relativização da oposição global / local; dicotomias, essas, que sustentavam a ordem moderna. Tanto a recorrência das catástrofes ditas naturais - cujas causas e efeitos tem profundas relações com o social e adquirirem no último século uma escala global - como o desenvolvimento recente de teorias sociais e científicas que desarticulam os limites entre natureza e cultura, exigem da arte contemporânea - e das leituras contemporâneas da arte- uma revisão de suas próprias condições geopolíticas, o que implica uma reconceituação da noção mesma de paisagem.

8 A presente edição oferece múltiplas entradas às problemáticas citadas acima, porém não as circunscreve a limites geopolíticos ou temporais em particular, tampouco correspondem a uma mesma disciplina ou prática cultural. Os temas abordados nos artigos, entrevistas, notas de exposições e resenhas de livros reunidos nesta edição, requerem necessariamente uma visão transdisciplinar. Ao mesmo tempo que os textos apoiam- se em casos particulares, seus autores estabelecem relações que explicitam o alcance global dos fenômenos abordados.

9 Reconhecendo nos artigos apresentados uma perspectiva social, os mesmos foram organizados de forma cronológica de modo a possibilitarem um desenvolvimento histórico das representações da natureza. Iniciando-se pelas construções pictóricas da paisagem, os artigos de Carla Hermann e María Beatriz H. Carrión abordam obras e artistas viajantes que a medida que transitam adquirem novos sentidos. $\mathrm{O}$ artigo de Jens 
Andermann integra esta mesma dimensão dinâmica ao estilo arquitetônico. Nos três casos citados, estes autores explicitam os alcances ideológicos de manifestações que convencionalmente haviam sido registrados como representativos e oficiais, fora de uma nação, bem como de uma localização em particular.

A geógrafa e historiadora da arte brasileira Carla Herman estuda os panoramas da cidade de Rio de Janeiro feitas pelo artista francês Félix Émile Taunay e o britânico Robert Burford, expostas em Paris e Londres, respectivamente. A autora analisa as diferentes estratégias desses artistas na representação da natureza na paisagem construída e exposta em território europeu, buscando compreender as estratégias e dinâmicas do olhar do outro em um duplo sentido que implica a condição estrangeira dos artistas e dos lugares de exposição.

11 A propósito desta questão da construção cultural de identidades e nacionalidades nas representações da natureza, a historiadora da arte equatoriana María Beatriz H. Carrión no artigo "Seduzindo al mundo: las imágenes de El Salvador en Chicago" analisa a representação da paisagem da costa do Equador no livro El Salvador en Chicago, obra comemorativa da participação deste país na Exposição de Chicago, em 1893; concluindo que na construção dessas paisagens buscou-se a construção de um país moderno e uma "natureza artificializada", que se distanciava das representações pictóricas do Equador elaboradas no bojo das construções pictóricas do sublime natural na arte de mediados do século XIX.

Por sua parte, o ensaísta alemão, especialista em estudos culturais latino-americanos Jens Andermann, analisa a construção social da paisagem da Patagônia Argentina no texto "Estilo austral: paisaje, arquitectura y regionalismo nacionalizador en el Parque Nacional Nahuel Huapi (1934-1943)". A partir do estudo do estilo arquitetônico e da configuração da paisagem no desenvolvimento do turismo na primeira metade do século XX, Andermann reconhece as dinâmicas coloniais de apropriação do território e revela as contradições de uma ordem moderna que se instala com formas diversas, mas igualmente impositivas das leis do mercado, da privatização dos hábitos e do gosto em regiões distantes da urbe.

13 Os trabalhos que tratam de manifestações artísticas contemporâneas apresentam uma perspectiva crítica pós - colonial em termos estéticos, assim como, de uma ética que perpassam as produções literárias, visuais, curatoriais, se constituindo em experiências de mundo natural e cultural esencialmente políticas. A propósito, o artigo da escritora e tradutora argentina Azucena Galenttini propõe uma reflexão em torno das evocações poéticas da natureza caribenha nas obras de autores que escrevem no idioma inglês, aproximando - se de uma imaginação da paisagem oriundas de experiências de desenraizamento e aculturação. $\mathrm{Na}$ análise de Azucena são evidenciadas as operações de desarticulação da visão exótica e idealizada da produção literária precedente (a produção considerada nacional e autêntica), e de correspondência com dinâmicas da exploração humana e artificial do território como marcas dessa poética caribenha contemporânea na língua inglesa.

Na mesma linha, o pesquisador e crítico cultural brasileiro Fábio Zucker escreve sobre a obra do Daniel Steegmann Mangrané, artista espanhol que mora no Brasil. Zucker vincula as sútis intervenções e instalações de Mangrané com modos de ver e se relacionar com o mundo indígena do Amazonas, guiando-se por observações antropológicas. A interdisciplinaridade presente na base da convocatória deste número materializa - se neste artigo. 

Barbosa Sánchez, "Representación del paisaje americano desde la perspectiva de la sustentabilidad", no qual elabora uma cartografia de artistas, investigadores e gestores da paisagem da América Latina, atentos à consciência ecológica relativas às mudanças climáticas, as chamadas catástrofes ambientais ou, dito de outra maneira, o processo de antropização que descreve nossa contemporaneidade.

Aproveitando a coincidência de eventos que ocorreram simultaneamente à elaboração desse número, a equipe editorial recebeu e elaborou uma série de colaborações em formato de vídeo entrevistas, comentários de exposições e resenhas de publicações. A exposição L'ateliê tropical: Jean-Baptiste Debret, peintres, écrivains et savants français au Brésil (1816-1850) comemora o bicentenário da Missão Artística Francesa ao Brasil. Exibida no Museu Castro Maya do Rio de Janeiro, e na Maison de l'Amérique Latine, em Paris, a exposição é comentada em entrevista com o curador e sociólogo da arte francês Jacques Leenhardt. O vídeo da exposição e a entrevista se complementam com a resenha da reedição da obra de Jean-Baptiste Debret, Voyage pittoresque et historique au Brésil com prefácio do mesmo Leenhardt, elaborada pelo curador e historiador da arte carioca, Raphael Fonseca.

A entrevista realizada pela historiadora da arte Marta Penhos ao pintor argentino Leonel Luna por ocasião da exposição Paisajes Americanos (curadoria de Cecília Cavanagh Pabeleón de las Artes da Universidad Católica de Buenos Aires, 2016) aborda a paisagem heterotópica, o pitoresco e o sublime revisitados pela visualidade contemporânea, especialmente na análise da obra Limites, que articula o passado com o presente no texto de Marta Penhos, com a história social do país. Na entrevista a autora analisa o tema da paisagem para o artista como uma ideia que se transforma continuamente e a adjetivação de Paisagem Americano, como a articulação entre geografia, território e lugares.

O historiador da arte brasileiro Renato Menezes entrevista o historiador Luis Márquez, especialista da arte renascentista que há alguns anos pesquisa sobre a história recente do capitalismo global e as condições da crise ambiental, direcionando seu potencial como pesquisador e ensaísta no desenvolvimento de uma escrita política e urgente.

19 Atendendo a contingência do campo artístico atual, a professora e crítica de arte brasileira Maria José Marcondes apresenta uma análise dos fundamentos conceituais da curadoria da $32^{\mathrm{a}}$ Bienal de São Paulo (2016), aproximando-se de obras de alguns autores ibero -americanos desde uma perspectiva pós - colonialista da cultura, reconhecendo em alguns trabalhos artísticos presentes, nesta edição da Bienal, a ativação de uma "epistemologia do sul", entendida como o resgate de culturas tradicionais e, a proposição de poéticas visuais em torno do tema da emergência ecológica.

20 O curador e crítico Gabriel Bogossian analisa as exposições A Queda do Céu (2015) e Resistências Contemporâneas (2016) com curadoria de Moacir dos Anjos no documento de trabalho "Um museu ausente: curadoria independente e ativismo indigenista, no âmbito da questão colocada neste Dossiê sobre práticas artísticas, antropológicas e / ou históricas em torno das relações entre natureza e cultura em sociedades indígenas da América Latina.

21 A atualidade das questões tratadas neste dossiê acerca de trabalhos de poéticas visuais nos quais paisagens heterotópicas, o pitoresco e o sublime são revisitados pela visualidade contemporânea é evidenciada na resenha apresentada por Maria Teresa 
Márquez sobre a exposição Hidropoética, expedições Antárticas, com curadoria de Ricardo Mancillas Garay, ( 2016 / 2017) no Museu de Arte Contemporáneo de Santiago (Chile) na qual diversos artistas trabalham com a temática da identidade, território e paisagem.

Por fim, outras duas resenhas abordam publicações recentes que ampliam o campo das relações entre arte, natureza e cultura, desde às perspectivas históricas, iconográficas e antropológicas. A primeira, elaborada pela historiadora da arte chilena Catalina Valdés, comenta o catálogo da exposição "Picturing the Americas. Landscape painting from Tierra del Fuego to the Artics", (2015), e outra, de Fabio Zucker, que apresenta o livro de Déborah Danowski e Eduardo Viveiros de Castro. Há um mundo por vir? Ensaios sobre medos e fins apresenta uma reflexão dos autores sobre o pensamento ameríndio (2014), obra que fundamenta vários dos argumentos utilizados pelos autores presentes neste dossiê.

\section{AUTORES}

JACQUES LEENHARDT

EHESS

MARIA JOSÉ DE AZEVEDO MARCONDES

Instituto de Artes, UNICAMP

CATALINA VALDÉS

EHESS/IDAES-Universidad Nacional de San Martín 